\title{
Synthesis and Photo- and Ionochromic and Spectral-Luminescent Properties of 5-Phenylpyrazolidin-3-one Azomethine Imines
}

\author{
Vladimir A. Bren (D), ${ }^{1}$ Alexander D. Dubonosov $\mathbb{D}^{\mathrm{D}}{ }^{2}$ Oksana S. Popova $\left(\mathbb{D},{ }^{1}\right.$ \\ Yurii V. Revinskii $\mathbb{D}^{2}{ }^{2}$ Karina S. Tikhomirova $\mathbb{D}^{1},{ }^{1}$ and Vladimir $\mathrm{I}$. Minkin $\mathbb{D}^{1,2}$ \\ ${ }^{1}$ Institute of Physical and Organic Chemistry, Southern Federal University, Rostov on Don, Russia \\ ${ }^{2}$ Southern Scientific Center, Russian Academy of Sciences, Rostov on Don, Russia \\ Correspondence should be addressed to Alexander D. Dubonosov; aled@ipoc.sfedu.ru
}

Received 29 June 2018; Accepted 1 September 2018; Published 23 September 2018

Academic Editor: Zofia Stasicka

Copyright (C) 2018 Vladimir A. Bren et al. This is an open access article distributed under the Creative Commons Attribution License, which permits unrestricted use, distribution, and reproduction in any medium, provided the original work is properly cited.

\begin{abstract}
Photochromic 5-phenylpyrazolidin-3-one-based azomethine imines containing 2-((1H-imidazol-2-yl)methylene) 1, 2-(pyridin-2ylmethylene) 2, 2-(quinolin-2-ylmethylene) 3, and 2-((8-hydroxyquinolin-2-yl)methylene) 4 substituents were synthesized. All the compounds exist in the ring-opened $\mathrm{O}$ forms. Under irradiation with light of $365 \mathrm{~nm}$, compounds $\mathbf{1 - 4}$ undergo thermally reversible isomerization into ring-closed bicyclic diaziridine isomers C. Azomethine imines 1-3 exhibit properties of ion-active molecular "off-on" switches of fluorescence when interacting with $\mathrm{F}^{-}$or $\mathrm{AcO}^{-}$anions. Compound 4 represents a bifunctional chemosensor demonstrating a colorimetric "naked-eye" effect for $\mathrm{Ni}^{2+}$ cation and complete fluorescence quenching in the presence of $\mathrm{H}^{+}, \mathrm{F}^{-}$, and $\mathrm{CN}^{-}$ions.
\end{abstract}

\section{Introduction}

Bistable photochromic compounds capable of reversible transformation between two stable isomeric forms are widely used in the design of materials for molecular electronics, optical data storage, optical switching, molecular logic devices, photopharmacology, biovisualization, and chemoand biosensors [1-7]. The most investigated classes of photochromes are spiropyrans and spirooxazines, diarylethenes, fulgides, and fulgimides [8] exhibiting positive photochromism with bathochromic spectral changes of the photoinduced isomers [9]. To a lesser extent, the compounds with negative photochromism [10]—norbornadienes [11, 12], acylotropic enaminoketones [13], and azomethine imines [14] - are described. Azomethine imine molecules possess a polar 1,3-dipole $\mathrm{N}^{-}-\mathrm{N}^{+}=\mathrm{C}$ fragment, which makes these compounds to be valuable precursors in the combinatorial chemistry of heterocycles prepared by cycloaddition reactions [15-21]. The resulting products containing a pyrazolidine cycle annulated to other heterocycles find application in medicine as the multipurpose biologically active compounds [22],
anti-HIV agents, inhibitors of NO synthase, and antidiabetic drugs [23-26], in agriculture [27, 28], and in other fields of science and technology [29]. Previously, it was shown that $N, N^{\prime}$-cyclic azomethine imines are capable of photochromic transformation due to reversible intramolecular cyclization [14, 30, 31]; however, the ionochromic and chemosensor properties of azomethine imines remained to be virtually unexplored.

We have recently reported the synthesis and characterization of a series of novel 5-phenylpyrazolidin-3-one-based azomethine imines, including photochromic compounds and systems sensitive to cations and anions [32, 33]. The combination of photochromic and ionochromic properties in one molecular system opens the pathway to polyfunctional compounds that may be in demand for the design of ionactive fluorescent molecular switches and colorimetric "naked-eye" reagents [2, 4, 34, 35]. Especially interesting are multi- and bifunctional ion-active molecular switches capable of independent recognition of two and more types of "guest" ions owing to specific spectral response through the same or different channels [36]. 
Herein, with the aim of obtaining multifunctional photoand ionochromic and fluorescent compounds, we report the synthesis of novel 5-phenylpyrazolidin-3-one-based azomethine imines containing $2-((1 H$-imidazol-2-yl $)$ methylene $)$ 1, 2-(pyridin-2-ylmethylene) 2, 2-(quinolin-2-ylmethylene) 3 , and 2-((8-hydroxyquinolin-2-yl)methylene) 4 substituents and the investigation of their photochromic, fluorescent, and chemosensor properties. The choice of heterocyclic substituents was motivated by the possibility of metal ion binding and $\mathrm{pH}$ sensitivity due to the electron-donating pyridine nitrogen atom, whereas the presence of $\mathrm{NH}(\mathrm{OH})$ groups may lead to anion detection [37].

\section{Experimental Section}

2.1. General. The IR spectra were recorded on a Varian Excalibur 3100 FT-IR instrument using the attenuated total internal reflection technique (ZnSe crystal). The ${ }^{1} \mathrm{H}$ and ${ }^{13} \mathrm{C} \mathrm{NMR}$ spectra in DMSO- $d_{6}$ were recorded on a Varian Unity 300 spectrometer $(300 \mathrm{MHz})$, the signals were referred with respect to the signals of residual protons of deutero-solvent (2.49 ppm), and $\delta$ values were measured with precision $0.01 \mathrm{ppm}$. Mass spectra were recorded on a Shimadzu GCMS-QP2010SE instrument with direct sample entry into the ion source (EI, $70 \mathrm{eV})$. The electronic absorption spectra were recorded on a Varian Cary 100 spectrophotometer. The irradiation of solutions in quartz cells $\left(l=1 \mathrm{~cm}, V=2 \cdot 10^{-3} \mathrm{~L}\right)$ with filtered light of a high-pressure Hg lamp (250 W) was performed on Newport 66941 equipment supplied with a set of interferential light filters. The intensity of light was $3.2 \cdot 10^{16}$ photons $\cdot \mathrm{s}^{-1}$ for the spectral line $365 \mathrm{~nm}$. The electronic emission spectra were recorded on a Varian Cary Eclipse spectrofluorimeter. Acetonitrile of spectroscopic grade, $d$-metal perchlorates, and tetra-butylammonium salts (Aldrich) were used to prepare solutions. Melting points were determined on a PTP $(\mathrm{M})$ instrument. The reaction progress and purity of the obtained compounds were controlled by TLC on Silufol U-254 plates using $\mathrm{CHCl}_{3}$ / $\mathrm{PrOH}=50: 1$ as eluent, and visualization was performed with iodine vapor in a moist chamber.

2.2. General Procedure for the Synthesis of Azomethine Imines (1-4). A solution of 5-phenylpyrazolidin-3-one [33] (1.62 g, $10 \mathrm{mmol})$ and the corresponding aldehyde $(10 \mathrm{mmol})$ in $2-\mathrm{PrOH}(25 \mathrm{~mL})$ was refluxed for $1.5 \mathrm{~h}$. The reaction mixture was cooled to room temperature. The solvent was removed on a rotary evaporator, and the residue was recrystallized from the corresponding solvent.

2.3. 2-((1H-Imidazol-2-yl)methylene)-5-oxo-3-phenylpyrazolidin2-ium-1-ide (1). Yield 37\%, colorless powder, m.p. 233$235^{\circ} \mathrm{C}$ (dec.) $(\mathrm{BuOH})$. IR $\left(\nu / \mathrm{cm}^{-1}\right): 3262,3113,3031,2984$, 2943, 1658, 1612, 1506, 1495, 1425, 1348, 1163, and 1072. ${ }^{1} \mathrm{H}$ NMR (DMSO-d6, $\left.300 \mathrm{MHz}, \mathrm{ppm}\right) \delta: 12.59$ (s, $1 \mathrm{H}$, $\mathrm{NH}), 7.43-7.35$ (m, 5H, $\mathrm{CH}_{\text {arom. }}$ ), 7.25 (s, $\left.1 \mathrm{H}, \mathrm{C}^{6} \mathrm{H}\right), 5.88$ (d. d, $\left.1 \mathrm{H}, J=4.0,4.3,9.4 \mathrm{~Hz}, \mathrm{C}^{5} \mathrm{H}\right), 3.24$ (d. d, $1 \mathrm{H}$, $\left.J=6.8, \quad 4.8, \quad 11.7 \mathrm{~Hz}, \quad \mathrm{C}^{4} \mathrm{H}\right), 2.64$ (d. d, $1 \mathrm{H}, \quad J=6.3$, $\left.4.4,16.4 \mathrm{~Hz}, \mathrm{C}^{4} \mathrm{H}\right) .{ }^{13} \mathrm{C} \mathrm{NMR}(75 \mathrm{MHz}, \mathrm{DMSO}-d 6, \mathrm{ppm})$ $\delta: 181.33\left(\mathrm{C}^{3}\right), 138.87\left(\mathrm{C}^{7}\right), 138.15\left(\mathrm{C}^{1 \prime}\right), 132.05\left(\mathrm{C}^{6}\right)$,
$129.21\left(C^{8}, C^{12}\right), 128.94\left(C^{10}\right), 126.66\left(C^{9}, C^{11}\right), 122.48$ $\left(\mathrm{C}^{3 \prime}\right), 121.52\left(\mathrm{C}^{4 \prime}\right), 70.71\left(\mathrm{C}^{5}\right)$, and $38.76\left(\mathrm{C}^{4}\right)$. EIMS, $70 \mathrm{eV}, \mathrm{m} / z$ (\%): 240 (38) $[\mathrm{M}]^{+}, 198$ (6), 136 (8), 108 (12), 105 (10), 104 (100). Anal. Calcd for $\mathrm{C}_{13} \mathrm{H}_{12} \mathrm{~N}_{4} \mathrm{O}$ : C, 64.99; H, 5.03; N, 23.22. Found: C, 64.78; H, 4.90; N, 23.11.

2.4. 5-Oxo-3-phenyl-2-(pyridin-2-ylmethylene)pyrazolidin-2ium-1-ide (2). Yield 65\%, colorless solid, m.p. $185-186^{\circ} \mathrm{C}$ (2-PrOH). IR $\left(v / \mathrm{cm}^{-1}\right): 3053,2986,2958,1679,1665,1579$, $1570,1557,1495,1454,1433,1394,1282,1259,1239,1195$, 1091, and 1080. ${ }^{1} \mathrm{H}$ NMR (DMSO-d6, $\left.300 \mathrm{MHz}, \mathrm{ppm}\right) \delta$ : $8.97\left(\mathrm{~d}, 1 \mathrm{H}, J=8.1 \mathrm{~Hz}, \mathrm{C}^{2 \prime} \mathrm{H}_{\text {arom. }}\right), 8.64(\mathrm{~d}, 1 \mathrm{H}, J=4.8 \mathrm{~Hz}$, $\left.\mathrm{C}^{5 \prime} \mathrm{H}_{\text {arom. }}\right), 7.98\left(\mathrm{t}, 1 \mathrm{H}, J=8.0 \mathrm{~Hz}, \mathrm{C}^{3 \prime} \mathrm{H}_{\text {arom. }}\right), 7.45-7.42$ $\left(\mathrm{m}, 5 \mathrm{H}, \mathrm{CH}_{\text {arom. }}\right.$ ), $7.22\left(\mathrm{~s}, 1 \mathrm{H}, \mathrm{C}^{6} \mathrm{H}\right), 6.00$ (d. d, $1 \mathrm{H}, J=4.8$, $9.6 \mathrm{~Hz}, \mathrm{C}^{5} \mathrm{H}$ ), 3.23 (d. d, $1 \mathrm{H}, J=9.7,16.6 \mathrm{~Hz}, \mathrm{C}^{4} \mathrm{H}$ ), 2.64 (d. d, $\left.1 \mathrm{H}, J=4.8,16.6 \mathrm{~Hz}, \mathrm{C}^{4} \mathrm{H}\right) .{ }^{13} \mathrm{C} \mathrm{NMR}(75 \mathrm{MHz}$, DMSO-d6, ppm) $\delta: 182.83\left(\mathrm{C}^{3}\right), 149.97\left(\mathrm{C}^{5 \prime}\right), 148.00\left(\mathrm{C}^{1 \prime}\right)$, $138.83\left(C^{7}\right), 136.97\left(C^{3 \prime}\right), 131.44\left(C^{6}\right), 129.28\left(C^{8}, C^{12}\right)$, $129.05\left(\mathrm{C}^{10}\right), 126.79\left(\mathrm{C}^{9}, \mathrm{C}^{11}\right), 125.95\left(\mathrm{C}^{2 \prime}\right), 124.83\left(\mathrm{C}^{4 \prime}\right)$, $73.19\left(\mathrm{C}^{5}\right)$, and $37.86\left(\mathrm{C}^{4}\right)$. EIMS, $70 \mathrm{eV}, \mathrm{m} / \mathrm{z}(\%): 251$ (10) $[\mathrm{M}]^{+}, 194$ (6), 120 (41), 119 (41), 105 (10), 104 (100). Anal. Calcd for $\mathrm{C}_{15} \mathrm{H}_{13} \mathrm{~N}_{3} \mathrm{O}$ : C, 71.70; H, 5.21; N, 16.72. Found: C, 71.59; H, 5.29; N, 16.62.

2.5. 5-Oxo-3-phenyl-2-(quinolin-2-ylmethylene)pyrazolidin2-ium-1-ide (3). Yield 64\%, colorless powder, m.p. 202$204^{\circ} \mathrm{C}$ (dec.) $(\mathrm{BuOH}) . \mathrm{IR}\left(\nu / \mathrm{cm}^{-1}\right): 3064,2990,1672,1575$, 1495, 1452, 1406, 1301, 1278, and 1072. ${ }^{1} \mathrm{H}$ NMR (DMSOd6, $300 \mathrm{MHz}, \mathrm{ppm}) \delta: 9.05\left(\mathrm{~d}, 1 \mathrm{H}, J=8.8 \mathrm{~Hz}, \mathrm{C}^{2 \prime} \mathrm{H}_{\text {arom. }}\right)$, $8.54\left(\mathrm{~d}, 1 \mathrm{H}, J=8.8 \mathrm{~Hz}, \mathrm{C}^{3 \prime} \mathrm{H}_{\text {arom }}\right), 8.06(\mathrm{~d}, 1 \mathrm{H}, J=8.4 \mathrm{~Hz}$, $\left.\mathrm{C}^{7 \prime} \mathrm{H}_{\text {arom. }}\right), 7.97\left(\mathrm{~d}, 1 \mathrm{H}, J=8.6 \mathrm{~Hz}, \mathrm{C}^{10 \prime} \mathrm{H}_{\text {arom. }}\right), 7.78(\mathrm{t}, 1 \mathrm{H}$, $\left.J=3.9 \mathrm{~Hz}, \mathrm{C}^{9 \prime} \mathrm{H}_{\text {arom. }}\right), 7.66\left(\mathrm{t}, 1 \mathrm{H}, J=7.8 \mathrm{~Hz}, \mathrm{C}^{8 \prime} \mathrm{H}_{\text {arom. }}\right)$, 7.50-7.42 (m, 5H, CH $\left.{ }_{\text {arom. }}\right), 7.39\left(\mathrm{~s}, 1 \mathrm{H}, \mathrm{C}^{6} \mathrm{H}\right), 6.05$ (d. d, $\left.1 \mathrm{H}, J=4.8,9.6 \mathrm{~Hz}, \mathrm{C}^{5} \mathrm{H}\right), 3.27$ (d. d, $1 \mathrm{H}, J=9.7,16.4 \mathrm{~Hz}$, $\mathrm{C}^{4} \mathrm{H}$ ), and 2.69 (d. d, $\left.1 \mathrm{H}, J=4.9,16.6 \mathrm{~Hz}, \mathrm{C}^{4} \mathrm{H}\right) .{ }^{13} \mathrm{C} \mathrm{NMR}$ (75 MHz, DMSO-d6, ppm) $\delta: 182.89\left(\mathrm{C}^{3}\right), 148.66\left(\mathrm{C}^{5 \prime}\right)$, $147.42\left(\mathrm{C}^{1 \prime}\right), 138.73\left(\mathrm{C}^{7}\right), 136.90\left(\mathrm{C}^{3 \prime}\right), 131.49\left(\mathrm{C}^{6}\right), 129.33$ $\left(C^{8}, C^{12}\right), 129.13\left(C^{10}\right), 128.95\left(C^{10 \prime}\right), 130.37\left(C^{9 \prime}\right), 127.35$ $\left(\mathrm{C}^{8 \prime}\right), 127.74\left(\mathrm{C}^{7 \prime}\right), 126.95\left(\mathrm{C}^{9}, \mathrm{C}^{11}\right), 128.14\left(\mathrm{C}^{4 \prime}\right), 122.15$ $\left(\mathrm{C}^{2 \prime}\right), 73.55\left(\mathrm{C}^{5}\right)$, and $37.84\left(\mathrm{C}^{4}\right)$. EIMS, $70 \mathrm{eV}, \mathrm{m} / \mathrm{z}(\%): 301$ (54) $[\mathrm{M}]^{+}, 300$ (26), 257 (12), 230 (8), 174 (12), 173 (100), 143 (31), 142 (25), 131(6), 116 (24), 115 (38), and 104 (16). Anal. Calcd for $\mathrm{C}_{19} \mathrm{H}_{15} \mathrm{~N}_{3} \mathrm{O}: \mathrm{C}, 75.73 ; \mathrm{H}, 5.02 ; \mathrm{N}, 13.94$. Found: C, 75.89; H, 5.09; N, 13.82 .

2.6. 2-((8-Hydroxyquinolin-2-yl)methylene)-5-oxo-3phenylpyrazolidin-2-ium-1-ide (4). Yield 35\%, yellow powder, m.p. $183-184^{\circ} \mathrm{C}$ (dioxane). IR $\left(\nu / \mathrm{cm}^{-1}\right): 3048,3028$, 2974, 2922, 2856, 1671, 1652, 1627, 1576, 1502, 1456, 1397, $1316,1286,1241,1196,1166$, and $1085 .{ }^{1} \mathrm{H}$ NMR (DMSOd6, $300 \mathrm{MHz}, \mathrm{ppm}) \delta: 9.96(\mathrm{~s}, 1 \mathrm{H}, \mathrm{OH}), 9.06$ (d, 1H, $J=8.8$ $\left.\mathrm{Hz}, \mathrm{C}^{2 \prime} \mathrm{H}_{\text {arom. }}\right), 8.45$ (d, $\left.1 \mathrm{H}, J=9.2 \mathrm{~Hz}, \mathrm{C}^{3 \prime} \mathrm{H}_{\text {arom. }}\right), 7.50-$ $7.37\left(\mathrm{~m}, 6 \mathrm{H}, \mathrm{CH}_{\text {arom. }}\right), 7.37\left(\mathrm{~s}, 1 \mathrm{H}, \mathrm{C}^{6} \mathrm{H}\right), 7.10(\mathrm{~d}, 1 \mathrm{H}$, $J=1.2 \mathrm{~Hz}, \mathrm{C}^{9 \prime} \mathrm{H}_{\text {arom. }}$ ), 6.08 (d. d, $1 \mathrm{H}, J=4.6,5.4,8.8 \mathrm{~Hz}$, $\mathrm{C}^{5} \mathrm{H}$ ), 3.26 (d. d, $\left.1 \mathrm{H}, J=9.7,16.6 \mathrm{~Hz}, \mathrm{C}^{4} \mathrm{H}\right), 2.67$ (d. d, $1 \mathrm{H}$, $\left.J=5.2, \quad 16.6 \mathrm{~Hz}, \mathrm{C}^{4} \mathrm{H}\right) .{ }^{13} \mathrm{C}$ NMR $(75 \mathrm{MHz}, \mathrm{DMSO}-d 6$, ppm) $\delta: 182.80\left(\mathrm{C}^{3}\right), 153.69\left(\mathrm{C}^{10 \prime}\right), 146.51\left(\mathrm{C}^{1 \prime}\right), 138.86$ 


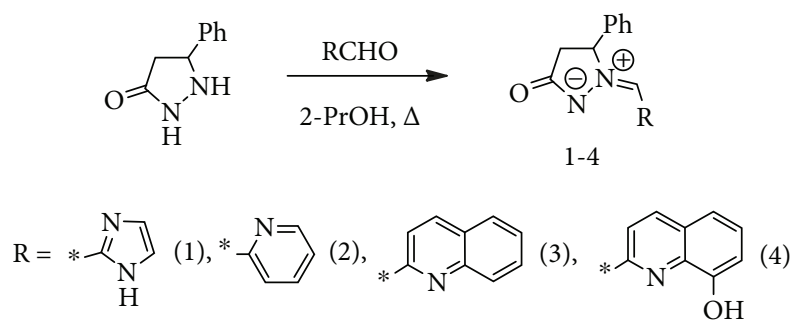

Scheme 1: Synthesis of azomethine imines 1-4.

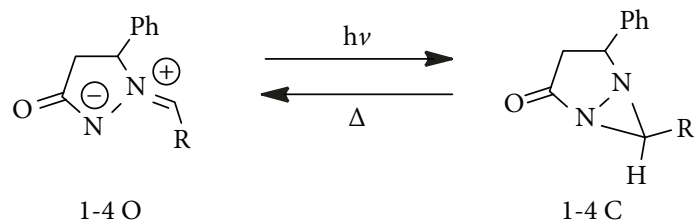

Scheme 2: Photochromic rearrangement of azomethine imines 1-4.

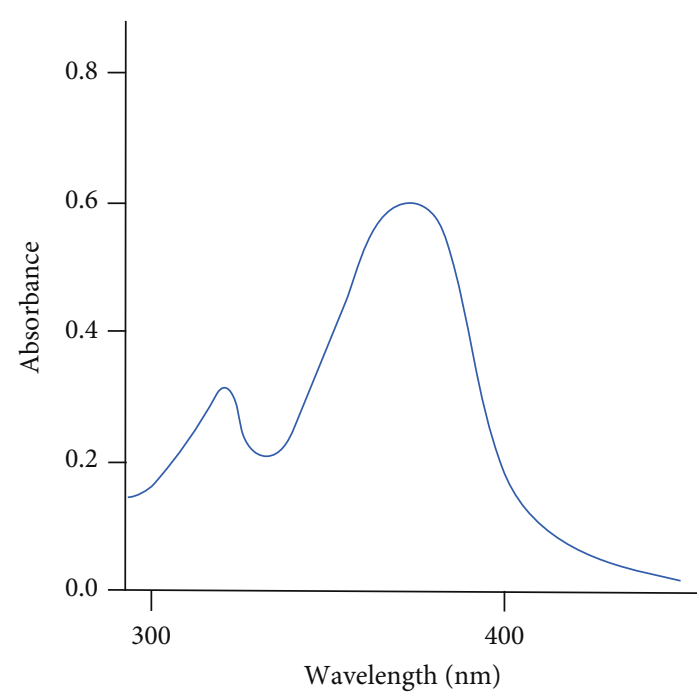

(a)

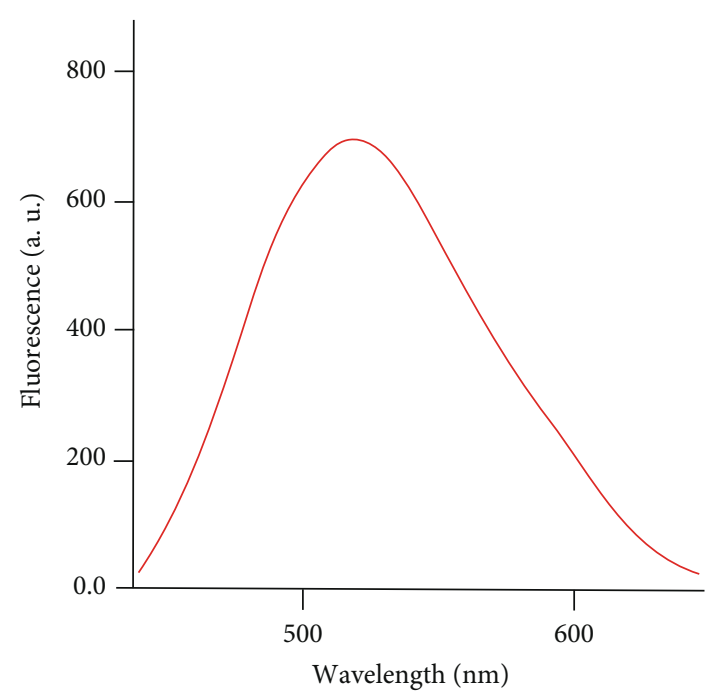

(b)

Figure 1: Electronic spectra of 4 in acetonitrile $\left(2.2 \cdot 10^{-5} \mathrm{M}\right)$ : (a) absorption and (b) emission $\left(\lambda_{\mathrm{ex}}: 370 \mathrm{~nm}\right)$.

$\left(C^{7 \prime}\right), 138.71\left(C^{5 \prime}\right), 136.71\left(C^{3 \prime}\right), 131.74\left(C^{6}\right), 129.48\left(C^{8 \prime}\right)$, $129.46\left(C^{8}, C^{12}\right), \quad 129.21\left(C^{10}\right), \quad 128.39\left(C^{4 \prime}\right), \quad 127.08$ $\left(C^{9}, \quad C^{11}\right), \quad 122.43 \quad\left(C^{2 \prime}\right), \quad 117.50 \quad\left(C^{7 \prime}\right), \quad 111.99 \quad\left(C^{9 \prime}\right)$, $73.48\left(\mathrm{C}^{5}\right)$, and $38.18\left(\mathrm{C}^{4}\right) .{ }^{15} \mathrm{~N}$ NMR $(75 \mathrm{MHz}, \mathrm{DMSO}-\mathrm{d} 6$, ppm) $\delta: 259.41\left(\mathrm{~N}^{1}\right), 273.71\left(\mathrm{~N}^{2}\right), 308.24\left(\mathrm{~N}^{6 \prime}\right)$. EIMS, $70 \mathrm{eV}, \mathrm{m} / z$ (\%): 317 (64) [M] $]^{+}, 160$ (14), 159 (100), 158 (89), 131 (15), 130 (24), 129 (20), 104 (10). Anal. Calcd for $\mathrm{C}_{19} \mathrm{H}_{15} \mathrm{~N}_{3} \mathrm{O}_{2}$ : C, 71.91; H, 4.76; N, 13.24. Found: C, 72.02; H, $4.89 ; \mathrm{N}, 13.32$.

\section{Results and Discussion}

Azomethine imines 1-4 were synthesized by condensation of 5-phenylpyrazolidin-3-one [33] with corresponding heterocyclic aldehydes (Scheme 1).
The IR spectra of 1-4 exhibit characteristic spectral bands of $\mathrm{C}=\mathrm{O}$ and $\mathrm{C}=\mathrm{N}^{+}$groups at $1658-1673 \mathrm{~cm}^{-1}$. The ${ }^{1} \mathrm{H}$ NMR spectra contain signals for the diastereotopic protons of the cyclic $\mathrm{CH}_{2}$ groups (two doublets of doublets at $2.93-3.38 \mathrm{ppm}$ ) and $\mathrm{CH}$ groups (a doublet of doublets at $5.56-5.68 \mathrm{ppm}$ ). Methine protons of $\mathrm{CH}=\mathrm{N}^{+}$fragments are observed as singlet signals in the region of $7.10-7.30 \mathrm{ppm}$. ${ }^{1} \mathrm{H}$ and ${ }^{13} \mathrm{C}$ NMR data corresponds to the ring-opened azomethine imine structure $\mathrm{O}$ (Scheme 2).

The electronic absorption spectra of ring-opened isomers 1-4 $\mathrm{O}$ in acetonitrile are characterized by longwavelength bands with maxima in the range of 321-364 and $351-380 \mathrm{~nm}$ as shown in the example of 4 (Figure 1, Table 1).

Compounds 1 and 2 are not fluorescent. Quinoline containing azomethine imine $\mathbf{3}$ possesses low-intensity fluorescence at $411 \mathrm{~nm}$, while 8 -hydroxyquinoline derivative 4 
TABLE 1: Electronic absorption and fluorescence spectra of isomeric forms of 1-4 in acetonitrile* .

\begin{tabular}{|c|c|c|c|c|c|}
\hline \multirow[b]{2}{*}{ Comp. } & \multicolumn{3}{|c|}{ Ring-opened form $\mathrm{O}$} & \multicolumn{2}{|c|}{ Ring-closed form C } \\
\hline & $\lambda_{\text {max }}^{\mathrm{abs}}, \mathrm{nm}$ & $\begin{array}{l}\text { Absorption } \\
\varepsilon_{\max } \cdot 10^{-4}, \mathrm{~L} \mathrm{~mol}^{-1} \mathrm{~cm}^{-1}\end{array}$ & Fluorescence, $\lambda_{\max }^{\mathrm{fl}}, \mathrm{nm}\left(I_{\mathrm{fl}}\right.$, a.u. $)$ & Absorption, $\lambda_{\text {max }}^{\mathrm{abs}}, \mathrm{nm}$ & $A$ \\
\hline 1 & 346,360 & $2.9,3.1$ & - & 241 & 0.21 \\
\hline 2 & 339,351 & $2.6,2.5$ & - & 261 & 0.12 \\
\hline 3 & $348,364,380$ & $3.8,4.7,4.0$ & $411(209)$ & 275,318 & $0.10,0.07$ \\
\hline 4 & 321,378 & $1.5,3.0$ & $514(430)$ & 249 & 0.88 \\
\hline
\end{tabular}

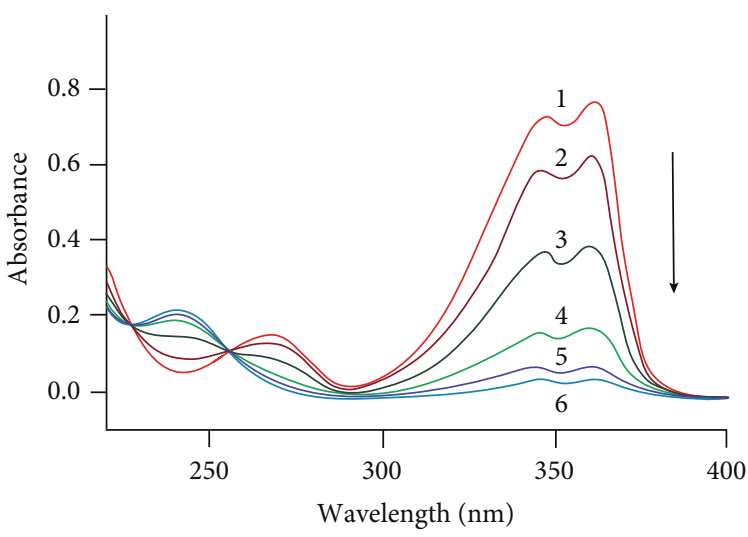

(a)

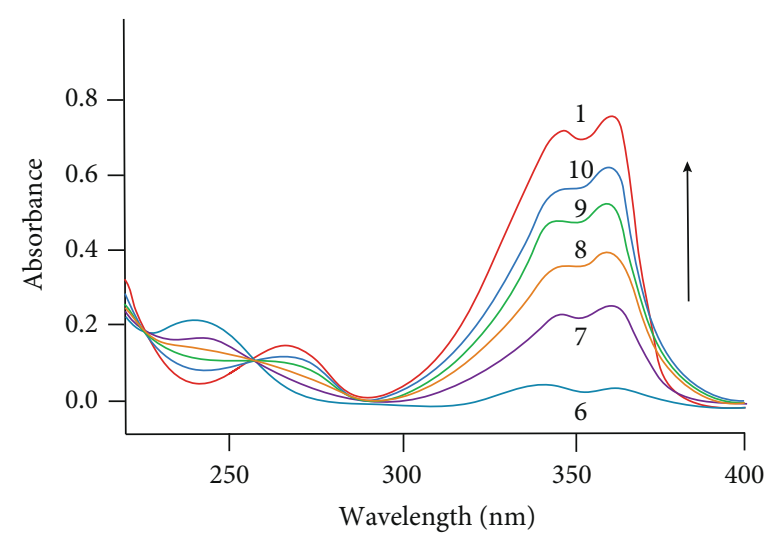

(b)

FIGURE 2: Electronic absorption spectra of 1 in acetonitrile $\left(3.0 \cdot 10^{-5} \mathrm{M}\right)$. (a) Before (1) and after $10 \mathrm{~s}(2), 20 \mathrm{~s}(3), 30 \mathrm{~s}(4), 40 \mathrm{~s}(5), 50 \mathrm{~s}(6)$, and $60 \mathrm{~s} \mathrm{(7)}$ of irradiation with light of $365 \mathrm{~nm}$. (b) Dark thermal inverse reaction: immediately after the end of irradiation (6), after $9 \mathrm{~s}(7), 17 \mathrm{~s}$ (8), $29 \mathrm{~s}$ (9), and $45 \mathrm{~s}(10)$.

demonstrates more intense emission with a larger Stokes shift at $514 \mathrm{~nm}(\varphi=0.03)$ (Table 1).

Irradiation of azomethine imine 1-4 O solutions in acetonitrile with light of $\lambda_{\text {irr }} 365 \mathrm{~nm}$ results in spectral changes in the characteristic of negative photochromism due to intramolecular photocyclization into diaziridines 1-4 C (Scheme 2), accompanied by a decrease in the intensity of long-wave absorption maxima and the appearance of absorption bands in the short-wave region of the spectrum $[10,30,31]$ as shown in Figure 2(a) in the example of compound $\mathbf{1}$ and in Table 1.

Thermal reopening of the diaziridine cycle in dark conditions after the end of irradiation is clearly observed only for $\mathbf{1}$ (Figure 2(b)); the lifetime of the photoproduct $1 \mathrm{C}$ was calculated as $\tau=1538 \mathrm{~s}$. In other cases, the photoproducts $2-4 \mathrm{C}$ were stable for 3-4 days.

The addition of metal cations (in the form of perchlorates) to solutions of 1-3 in acetonitrile does not lead to noticeable spectral changes. In contrast, the interaction of $\mathbf{4}$ with $\mathrm{Zn}^{2+}, \mathrm{Hg}^{2+}$, and $\mathrm{Ni}^{2+}$ cations results in the appearance of novel long-wave absorption bands at $486-582 \mathrm{~nm}$ (Figure 3). A particularly distinct "naked-eye" effect (change of solution color from pale yellow to dark blue) was observed for Ni (II). These color changes are accompanied by almost complete quenching of the fluorescence of the initial solution (Figure 3 (inset)).

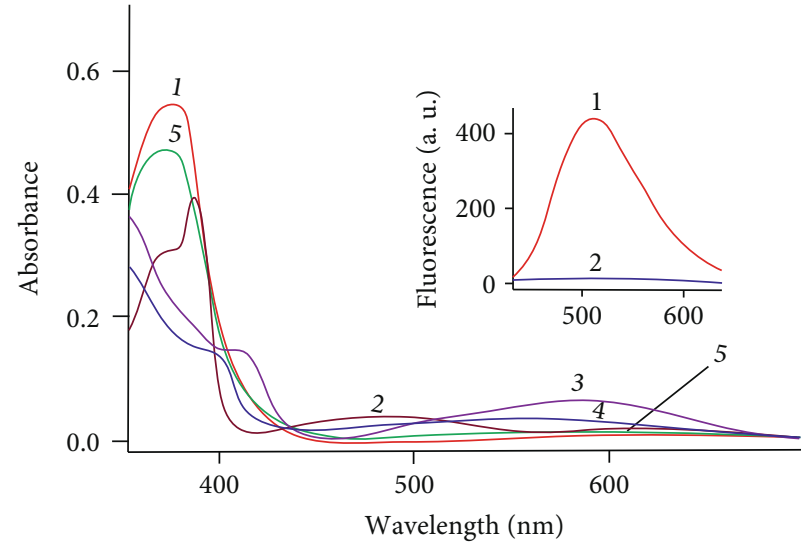

FIgURE 3: Electronic absorption spectra of $\mathbf{4}$ in acetonitrile $\left(2.0 \cdot 10^{-5} \mathrm{M}\right)$ before $(1)$ and after addition of metal cations (in the form of perchlorates) $\mathrm{Zn}^{2+}(2), \mathrm{Ni}^{2+}$ (3), $\mathrm{Hg}^{2+}$ (4), and $\mathrm{Co}^{2+}(5)$ $\left(2.0 \cdot 10^{-4} \mathrm{M}\right)$; inset: fluorescence before $(1)$ and after addition of $\mathrm{Hg}^{2+}(2)$.

The addition of tetra-butylammonium salts (TBAX: $\mathrm{X}=\mathrm{F}$, $\mathrm{Cl}, \mathrm{H}_{2} \mathrm{PO}_{4}, \mathrm{CN}, \mathrm{AcO}$, and $\mathrm{ClO}_{4}$ ) to solutions of compounds 1-4 in acetonitrile results in changes in both absorption and fluorescence spectra (Figures 4 and 5, Table 2). 


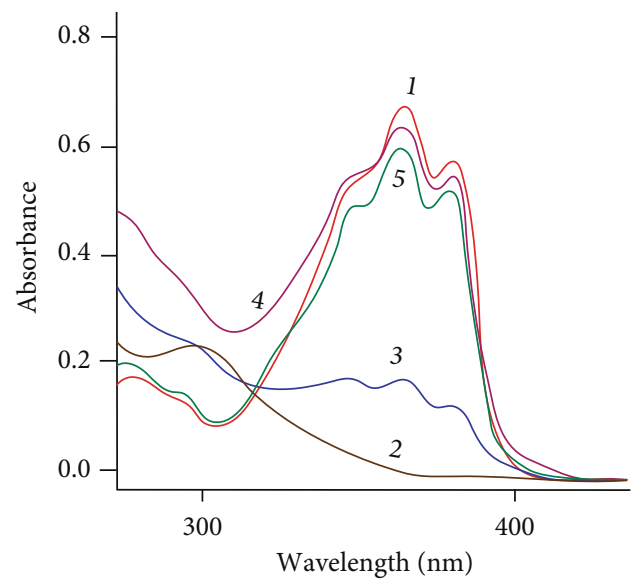

(a)

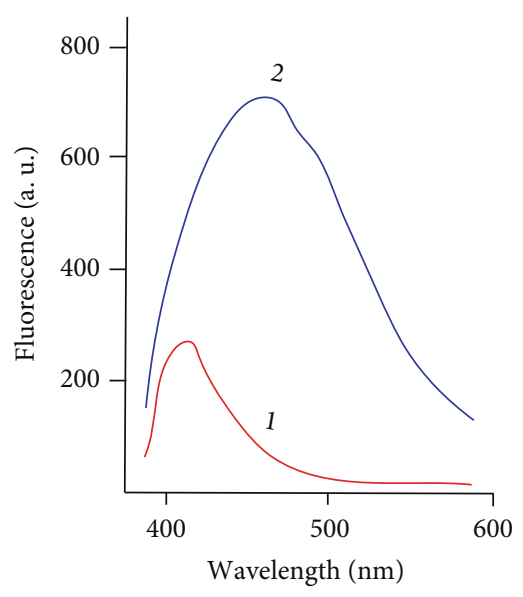

(b)

Figure 4: Electronic spectra of 3 in acetonitrile $\left(2.0 \cdot 10^{-5} \mathrm{M}\right)$. (a) Absorption before (1) and after addition of $\mathrm{F}^{-}$(3), $\mathrm{CN}^{-}(2), \mathrm{AcO}^{-}(4)$, and $\mathrm{H}_{2} \mathrm{PO}_{4}{ }^{-}$(5) $\left(2.0 \cdot 10^{-4} \mathrm{M}\right)$. (b) Fluorescence before (1) and after addition of $\mathrm{F}^{-}(2)$.

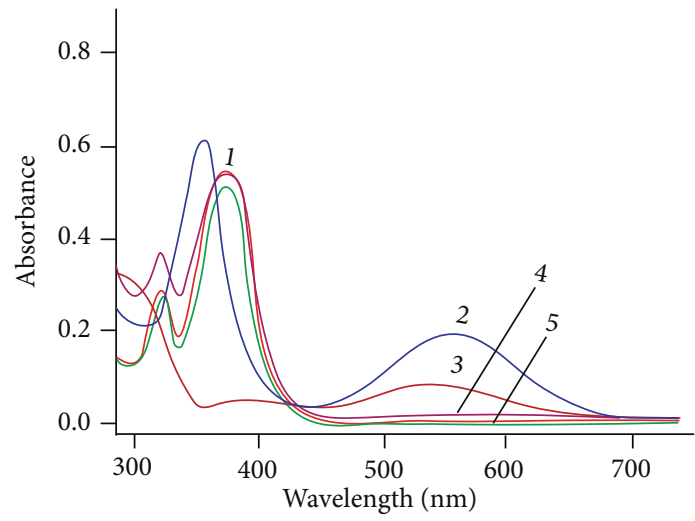

(a)

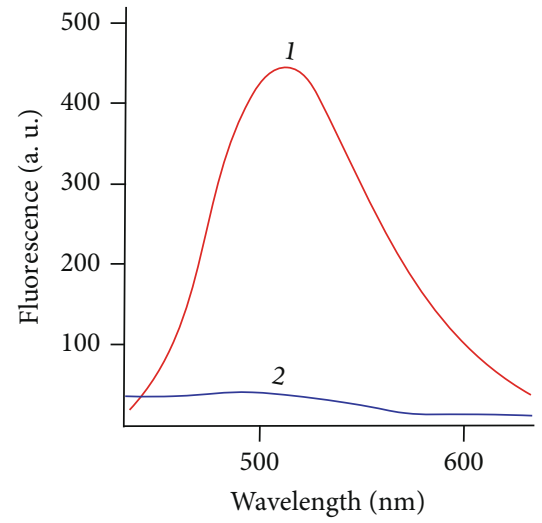

(b)

FIGURE 5: Electronic spectra of 4 in acetonitrile $\left(2.0 \cdot 10^{-5} \mathrm{M}\right)$. (a) Absorption before (1) and after addition of $\mathrm{F}^{-}(2), \mathrm{CN}^{-}(3), \mathrm{AcO}^{-}(4)$, and $\mathrm{H}_{2} \mathrm{PO}_{4}^{-}(5)\left(2.0 \cdot 10^{-4} \mathrm{M}\right)$. (b) Fluorescence before (1) and after addition of $\mathrm{F}^{-}$(2).

TABLE 2: Changes in position $\left(\lambda_{\text {max }}^{\mathrm{fl}}\right)$ and fluorescence intensity $\left(I_{\mathrm{fl}}\right)$ of compounds $\mathbf{1 - 4}\left(3 \cdot 10^{-5} \mathrm{M}\right)$ in acetonitrile upon addition of anions (in the form of TBAX salts) $\left(1.0 \cdot 10^{-4} \mathrm{M}\right)$.

\begin{tabular}{lccccc}
\hline Comp. & $\mathrm{No}$ & $\mathrm{F}^{-}$ & $\mathrm{CN}^{-}$ & $\mathrm{AcO}^{-}$ & $\mathrm{ClO}_{4}^{-}$ \\
\hline $\mathbf{1}$ & - & $425(920)$ & - & $420(645)$ & - \\
$\mathbf{2}$ & - & $460(825)$ & $460(700)$ & $446(370)$ & $420(890)$ \\
$\mathbf{3}$ & $411(209)$ & - & - & $417(480)$ & - \\
$\mathbf{4}$ & $514(430)$ & $502(430)$ & $514(430)$ \\
\hline
\end{tabular}

Binding of fluoride anion with quinoline containing azomethine imine 3 causes almost complete diminishing intensity of the $364 \mathrm{~nm}$ band. At the same time, the emission maximum shifts to the longer-wavelength region at $460 \mathrm{~nm}$ and its intensity sharply increases (Figure 4).

On the contrary, coordination of fluoride anion with 8-hydroxyquinoline containing azomethine imine 4 is accompanied by a pronounced "naked-eye" effect (change in solution color from yellow to bright purple) due to the appearance of a new absorption band at $555 \mathrm{~nm}$ (Figure 5(a)). However, in this case, the initial emission of $\mathbf{4}$ is almost completely quenched (Figure 5(b)).

Interaction of nonfluorescent compounds $\mathbf{1}$ and $\mathbf{2}$ with tetra-butylammonium salts in acetonitrile does not 


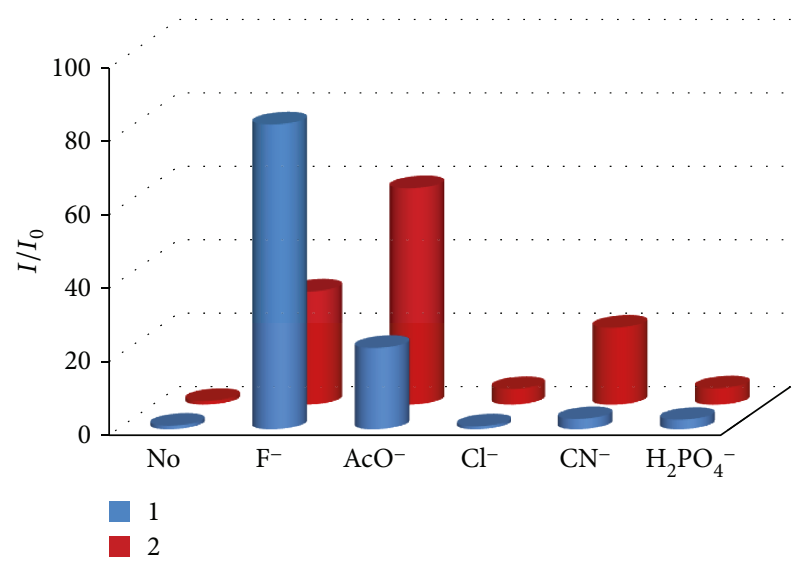

FIGURE 6: Relative changes of fluorescence intensity $\left(I / I_{0}\right)$ of compounds 1 and 2 in acetonitrile $\left(2.0 \cdot 10^{-6} \mathrm{M}\right)$ in the presence of anions $\left(2.0 \cdot 10^{-5} \mathrm{M}\right)$.

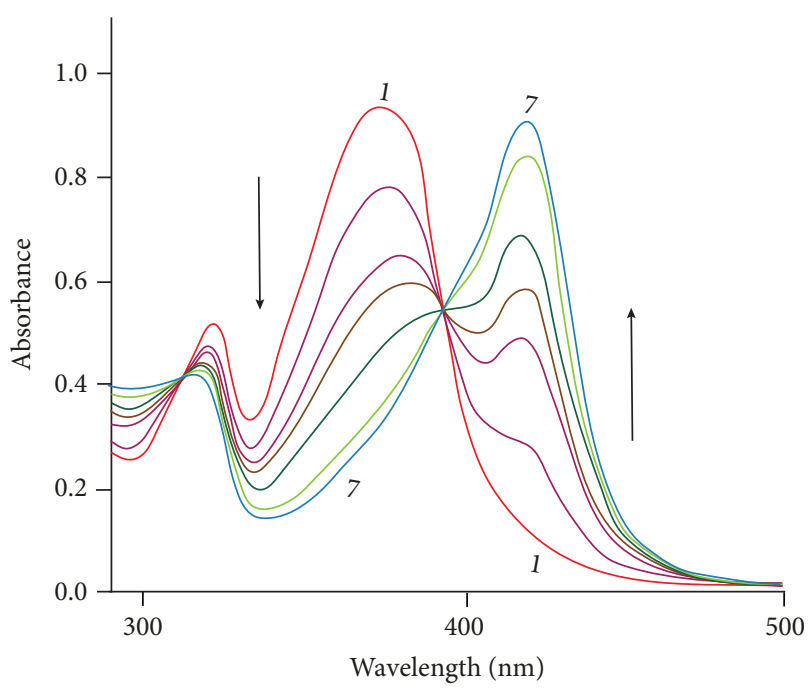

Figure 7: Electronic absorption spectra of 4 in acetonitrile $\left(3.0 \cdot 10^{-5} \mathrm{M}\right)$ before $(1)$ and after addition of $\mathrm{CF}_{3} \mathrm{COOH}: 1 \cdot 10^{-4}$ $\mathrm{M}(2), 2 \cdot 10^{-4} \mathrm{M}(3), 3 \cdot 10^{-4} \mathrm{M}(4), 5 \cdot 10^{-4} \mathrm{M}(5), 1.0 \cdot 10^{-3} \mathrm{M}(6)$, and $1.5 \cdot 10^{-3} \mathrm{M}(7)$.

significantly affect the absorption spectra but causes "on-off" switching of fluorescence at 425 and $460 \mathrm{~nm}$ in the presence of fluoride and acetate anions, respectively (Table 2, Figure 6).

Compounds 2-4 possessing a pyridine-type nitrogen atom exhibit pronounced acidochromic properties [9], whereas $\mathbf{1}$ is practically not sensitive to $\mathrm{pH}$ of the solution. For example, a decrease in the $\mathrm{pH}$ when adding trifluoroacetic acid to acetonitrile solution of 4 results in the appearance of wavelength absorption band at $419 \mathrm{~nm}$ and a decrease in the absorption intensity of the initial $374 \mathrm{~nm}$ band (Figure 7).

New maxima of acid-induced colored form of compounds 2 and 3 are located at 385 and $424 \mathrm{~nm}$, respectively. Azomethine imines $\mathbf{3}$ and $\mathbf{4}$ are also pH-controllable "on-off" molecular switches of fluorescent properties. During acidification, the intensity of initial emission at 411 (3) and $514 \mathrm{~nm}(4)$ is gradually reduced until complete quenching.

\section{Conclusions}

To sum up, the synthesized 5-phenylpyrazolidin-3-one azomethine imines containing 2-((1H-imidazol-2-yl)methylene) 1, 2-(pyridin-2-ylmethylene) 2, 2-(quinolin-2-ylmethylene) 3 , and 2-((8-hydroxyquinolin-2-yl)methylene) 4 substituents exist in the ring-opened $\mathrm{O}$ forms. Irradiation of their acetonitrile solutions with UV light of $365 \mathrm{~nm}$ results in thermally reversible transformation into the ring-closed bicyclic diaziridine isomers 1-4 C. Nonfluorescent compounds 1 and 2 exhibit selective "off-on" emission switching in the presence of $\mathrm{F}^{-}$and $\mathrm{AcO}^{-}$anions that cause an increase in fluorescence intensity in 30 and 20 times (1) and in 80 and 60 times (2), respectively. Azomethine imines $\mathbf{3}$ and $\mathbf{4}$ are bifunctional molecular switches capable of both inflaming (with $\mathrm{F}^{-}$and $\mathrm{AcO}^{-}$anions) or complete quenching of emission (with $\mathrm{H}^{+}$cation). 2-((8-Hydroxyquinolin-2-yl)methylene)-5-oxo3-phenylpyrazolidin-2-ium-1-ide 4 represents a bifunctional chemosensor demonstrating a pronounced "naked-eye" colorimetric effect for $\mathrm{Ni}^{2+}$ cation detection and fluorescence quenching in the presence of $\mathrm{H}^{+}, \mathrm{F}^{-}$, and $\mathrm{CN}^{-}$ions.

\section{Data Availability}

The data used to support the findings of this study are available from the corresponding author upon request.

\section{Conflicts of Interest}

The authors declare that there is no conflict of interests regarding the publication of this paper.

\section{Acknowledgments}

This work was carried out in the framework of the basic part of State Task in the Sphere of Scientific Activity (nos. 4.6497.2017/8.9 and 4.5593.2017/6.7) and State Task of SSC RAS no. 01201354239.

\section{References}

[1] Y. Yokoyama and K. Nakatani, Eds., Photon-Working Switches, Springer, 2017.

[2] B. L. Feringa and W. R. Browne, Eds., Molecular Switches, Wiley, Weinheim, Germany, 2011.

[3] W. A. Velema, W. Szymanski, and B. L. Feringa, "Photopharmacology: beyond proof of principle," Journal of the American Chemical Society, vol. 136, no. 6, pp. 2178-2191, 2014.

[4] J. Andreasson and U. Pischel, "Molecules with a sense of logic: a progress report," Chemical Society Reviews, vol. 44, no. 5, pp. 1053-1069, 2015.

[5] J. Zhang, Q. Zou, and H. Tian, "Photochromic materials: more than meets the eye," Advanced Materials, vol. 25, no. 3, pp. 378-399, 2013.

[6] G. Wang and J. Zhang, "Photoresponsive molecular switches for biotechnology," Journal of Photochemistry and Photobiology C, vol. 13, no. 4, pp. 299-309, 2012.

[7] M. Natali and S. Giordani, "Molecular switches as photocontrollable "smart" receptors," Chemical Society Reviews, vol. 41, no. 10, pp. 4010-4029, 2012. 
[8] J. C. Crano and R. J. Guglielmetti, Eds., Organic Photochromic and Thermochromic Compounds, Plenum Press, New York, NY, USA, 1999.

[9] H. Bouas-Laurent and H. Dürr, "Organic photochromism (IUPAC technical report)," Pure and Applied Chemistry, vol. 73, no. 4, pp. 639-665, 2001.

[10] S. Aiken, R. J. L. Edgar, C. D. Gabbutt, B. M. Heron, and P. A. Hobson, "Negatively photochromic organic compounds: exploring the dark side," Dyes and Pigments, vol. 149, pp. 92-121, 2018.

[11] A. D. Dubonosov, V. A. Bren, and V. I. Minkin, "The photochemical reactivity of Norbornadiene-Quadricyclane System," in Handbook of Organic Photochemistry and Photobiology, W. M. Horspool and F. Lenci, Eds., pp. 1-34, CRC Press, Boca Raton, FL, USA, 2nd edition, 2004

[12] A. Lennartson, A. Roffey, and K. Moth-Poulsen, "Designing photoswitches for molecular solar thermal energy storage," Tetrahedron Letters, vol. 56, no. 12, pp. 1457-1465, 2015.

[13] A. D. Dubonosov, V. I. Minkin, V. A. Bren et al., "Photochromic 2-(N-acyl-N-arylaminomethylene)benzo[b]thiophene$3(2 \mathrm{H})$-ones with fluorescent labels and/or crown-ether receptors," ARKIVOC, vol. 2003, no. 13, pp. 12-20, 2003.

[14] M. G. Kuzmin and M. V. Kozmenko, "Luminescence of photochromic compounds," in Organic Photochromes, A. V. El'tsov, Ed., pp. 245-265, Plenum Press, N-Y, London, 1990.

[15] T. Hashimoto, H. Kimura, Y. Kawamata, and K. Maruoka, "Generation and exploitation of acyclic azomethine imines in chiral Brønsted acid catalysis," Nature Chemistry, vol. 3, no. 8, pp. 642-646, 2011.

[16] M. I. Pleshchev, V. Y. Petukhova, V. V. Kuznetsov et al., "Generation and metathesis of azomethine imines in reaction of 6-aryl-1,5-diazabicyclo[3.1.0]hexanes with het(aryl)methylidenemalononitriles," Russian Chemical Bulletin, vol. 62, no. 4, pp. 1066-1075, 2013.

[17] S. Milosevic and A. Togni, "Enantioselective 1,3-dipolar cycloaddition of $\mathrm{C}, \mathrm{N}$-cyclic azomethine imines to unsaturated nitriles catalyzed by $\mathrm{Ni}^{\mathrm{II}}$-Pigiphos," Journal of Organic Chemistry, vol. 78, no. 19, pp. 9638-9646, 2013.

[18] H. D. S. Guerrand, H. Adams, and I. Coldham, "Cascade cyclization, dipolar cycloaddition of azomethine imines for the synthesis of pyrazolidines," Organic \& Biomolecular Chemistry, vol. 9, no. 22, pp. 7921-7928, 2011.

[19] C. Shao, Q. Zhang, G. Cheng, C. Cheng, X. Wang, and Y. Hu, "Copper(I) acetate-catalyzed cycloaddition between azomethine imines and propiolates under additive-free conditions," European Journal of Organic Chemistry, vol. 2013, no. 28, pp. 6443-6448, 2013.

[20] C. Nájera, J. M. Sansano, and M. Yus, "1, 3-Dipolar cycloadditions of azomethine imines," Organic \& Biomolecular Chemistry, vol. 13, no. 32, pp. 8596-8636, 2015

[21] N. P. Belskaya, V. A. Bakulev, and Z. Fan, "Synthesis and (3+2) cycloaddition reactions of $N, N$ '- and $C, N$-cyclic azomethine imines," Chemistry of Heterocyclic Compounds, vol. 52, no. 9, pp. 627-636, 2016.

[22] I. Panfil, Z. Urbańczyk-Lipkowska, K. Suwińska, J. Solecka, and M. Chmielewski, "Synthesis of pyrazolidinone analogs of $\beta$-lactam antibiotics," Tetrahedron, vol. 58, no. 6, pp. 11991212, 2002.

[23] L. N. Jungheim and S. K. Sigmund, "1, 3-Dipolar cycloaddition reactions of pyrazolidinium ylides with acetylenes. Synthesis of a new class of antibacterial agents," Journal of Organic Chemistry, vol. 52, no. 18, pp. 4007-4013, 1987.

[24] L. N. Jungheim, "Bicyclic pyrazolidinone antibacterial agents. Synthesis of side chain analogues of carbapenems PS-5 and thienamycin," Tetrahedron Letters, vol. 30, no. 15, pp. 1889$1892,1989$.

[25] M. P. Clark, S. K. Laughlin, M. J. Laufersweiler et al., "Development of orally bioavailable bicyclic pyrazolones as inhibitors of tumor necrosis factor- $\alpha$ production," Journal of Medicinal Chemistry, vol. 47, no. 11, pp. 2724-2727, 2004.

[26] T. Arai and Y. Ogino, "Chiral Bis(Imidazolidine)pyridine- $\mathrm{Cu}$ complex-catalyzed enantioselective [3+2]-cycloaddition of azomethine imines with propiolates," Molecules, vol. 17, no. 5, pp. 6170-6178, 2012.

[27] J. M. Indelicato and C. E. Pasini, "The acylating potential of gamma-lactam antibacterials: base hydrolysis of bicyclic pyrazolidinones," Journal of Medicinal Chemistry, vol. 31, no. 6, pp. 1227-1230, 1988.

[28] B. L. Walworth, "1, 2-Dialkyl-3(or 3, 5)-N-heterocyclic pyrazolium salts or derivatives thereof as fungicidal agents," 1978, US Patent 4091106A.

[29] P. J. Alarco, Y. Abu-Lebdeh, and M. Armand, "Highly conductive, organic plastic crystals based on pyrazolium imides," Solid State Ionics, vol. 175, no. 1-4, pp. 717-720, 2004.

[30] G. Geissler, I. Menz, K. Angermüller, and G. Tomaschewski, "Azomethinimine. VI. Zum thermischen Verhalten des photochromiesystems azomethinimin/diaziridin, untersucht an pyrazolidon-(3)-azomethiniminen und deren photoprodukten," Journal für Praktische Chemie, vol. 325, no. 2, pp. 197-204, 1983.

[31] M. Schulz and G. West, "Photochemische reaktionen von pyrazolidon-(3)-betainen. II synthese der $\beta$-hydrazino-isovaleriansäure," Journal für Praktische Chemie, vol. 315, no. 4, pp. 711-716, 1973.

[32] O. S. Popova, V. A. Bren', V. V. Tkachev et al., "Synthesis and structure of 1-[(3-hydroxybenzo[b]thiophen-2-yl)methylidene]-3-oxo-5-phenyl-1-pyrazolidinium-2-ide," Doklady Chemistry, vol. 471, no. 1, pp. 311-313, 2016.

[33] V. A. Bren, O. S. Popova, I. E. Tolpygin, V. A. Chernoivanov, Y. V. Revinskii, and A. D. Dubonosov, "New ionochromic azomethinimine chemosensors," Russian Chemical Bulletin, vol. 64, no. 3, pp. 668-671, 2015.

[34] A. Bianchi, E. Delgado-Pinar, E. Garcia-Espana, C. Giorgi, and F. Pina, "Highlights of metal ion-based photochemical switches," Chemical Society Reviews, vol. 260, pp. 156-215, 2014.

[35] G. Ghale and W. M. Nau, "Dynamically analyte-responsive macrocyclic host-fluorophore systems," Accounts of Chemical Research, vol. 47, no. 7, pp. 2150-2159, 2014.

[36] L. Yu, S. Wang, K. Huang, Z. Liu, F. Gao, and W. Zeng, "Fluorescent probes for dual and multi analyte detection," Tetrahedron, vol. 71, no. 29, pp. 4679-4706, 2015.

[37] N. Kaur, G. Kaur, U. A. Fegade et al., "Anion sensing with chemosensors having multiple NH recognition units," Trends in Analytical Chemistry, vol. 95, pp. 86-109, 2017. 

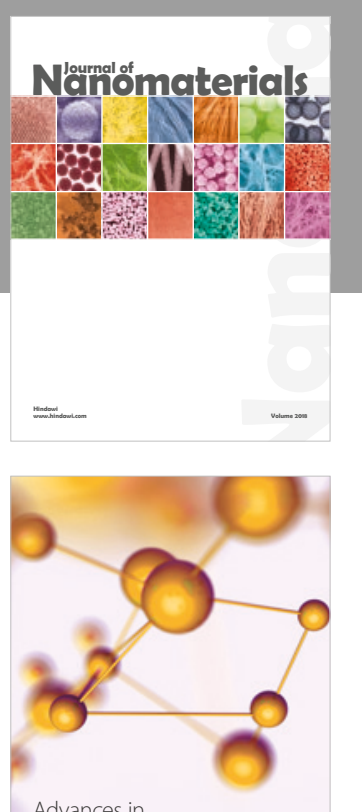

Physical Chemistry
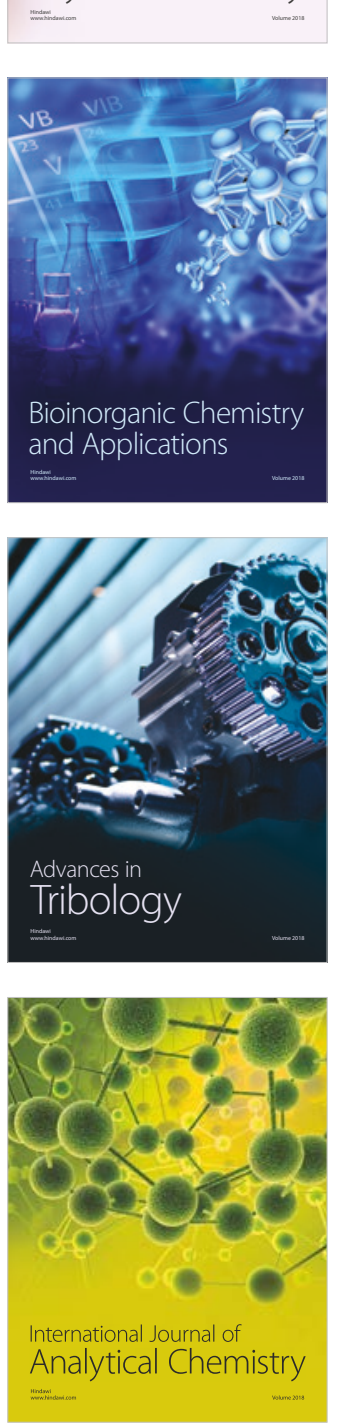

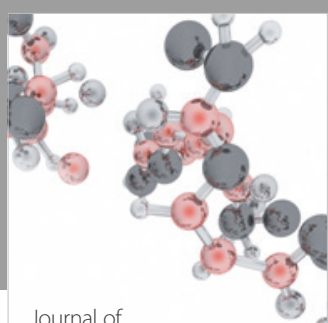

Analytical Methods

in Chemistry

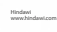

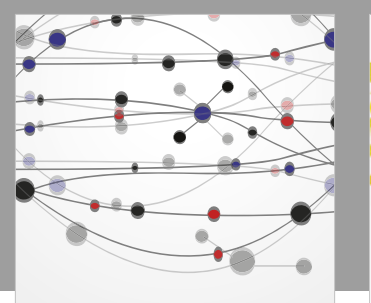

The Scientific World Journal

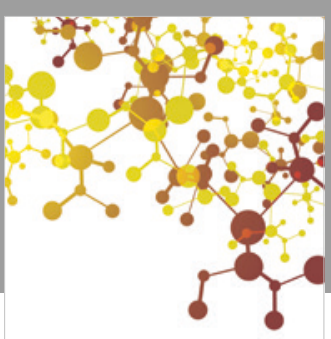

Journal of

Applied Chemistry
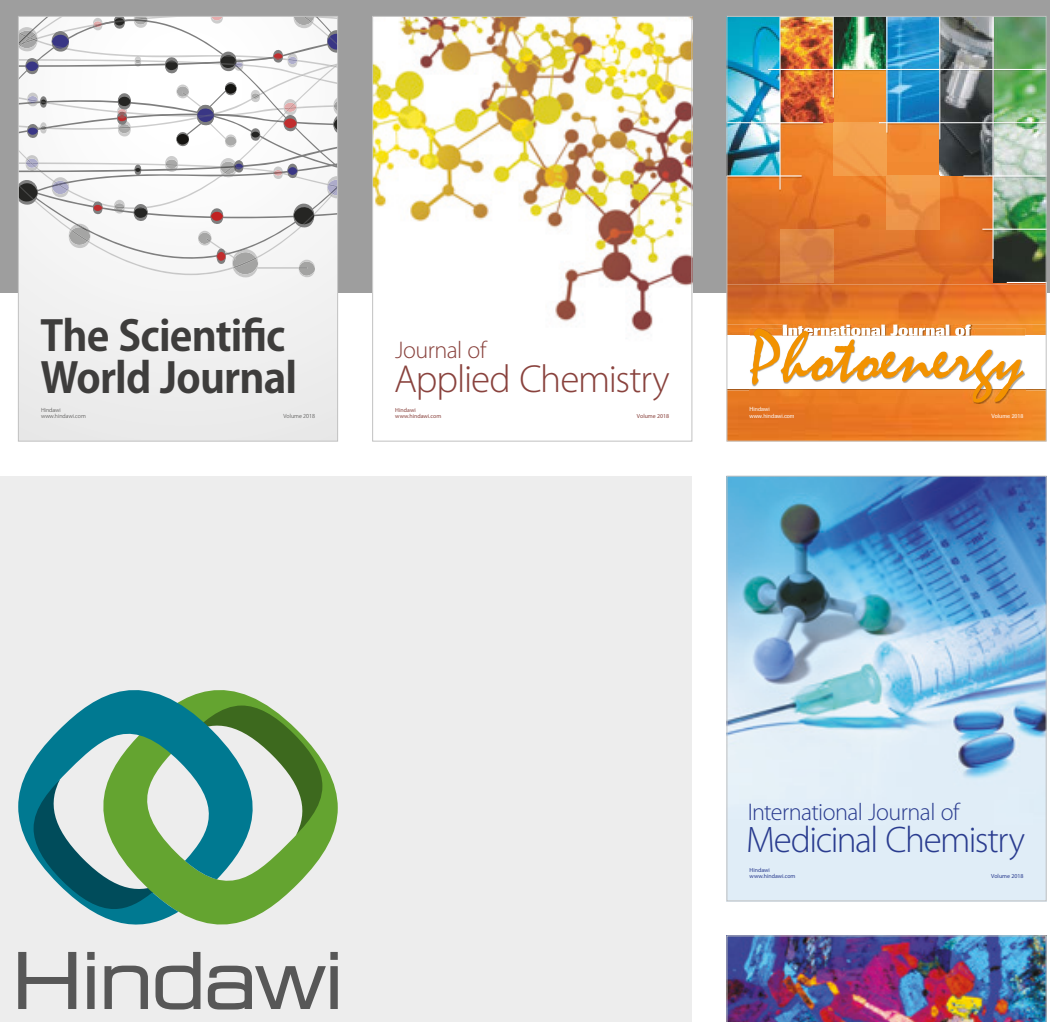

Submit your manuscripts at

www.hindawi.com
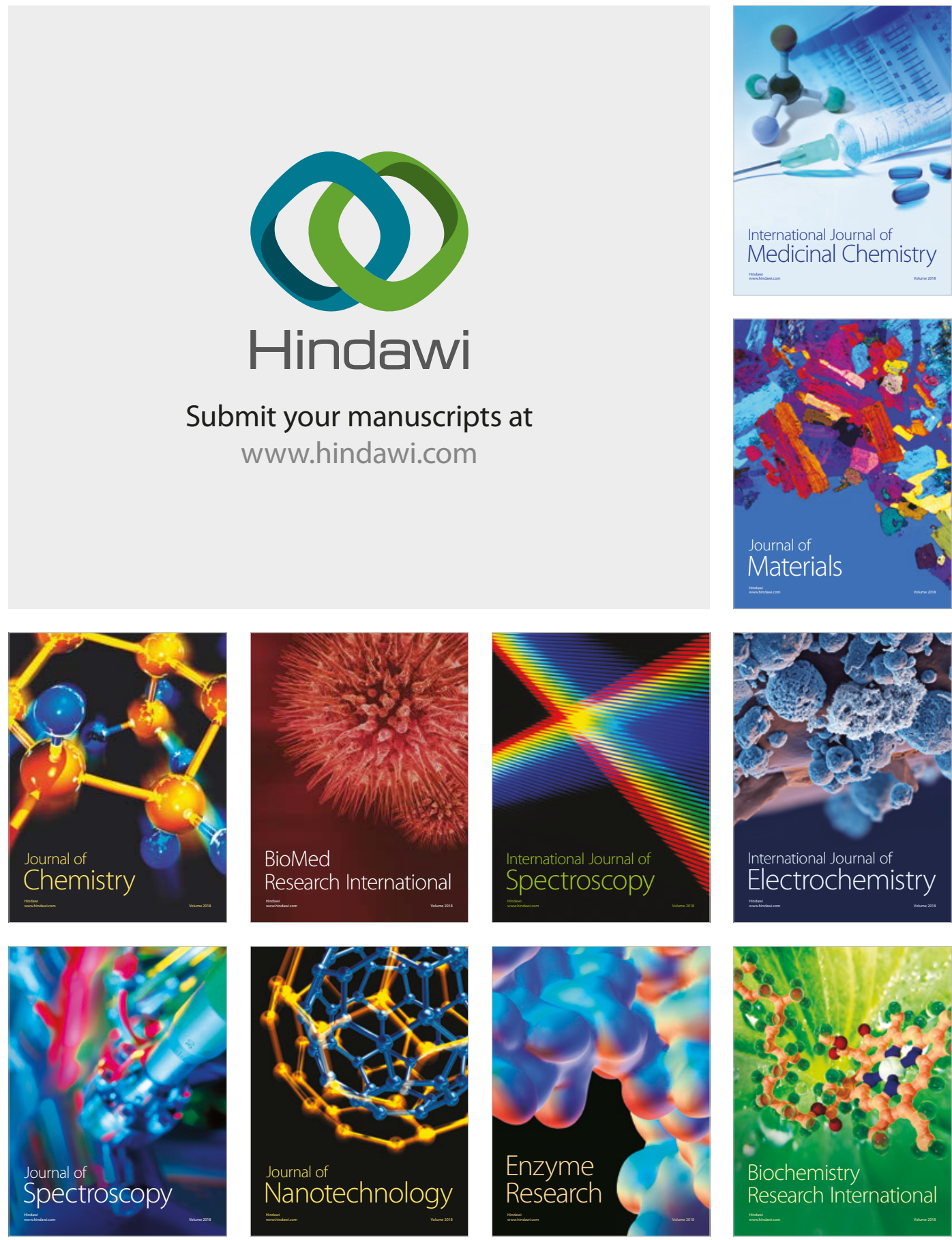
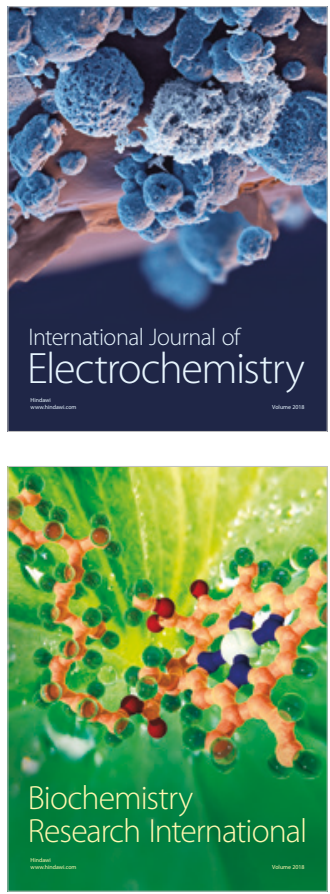